FARKAS TAMÁS - SLÍZ MARIANN szerk., Tulajdonnevek és szótárak. ELTE Magyar Nyelvtudományi és Finnugor Intézet - Magyar Nyelvtudományi Társaság, Budapest, 2020. 39-52. DOI: 10.26546/4892373.3

\title{
Tulajdonnevek a történeti és etimológiai szótárakban*
}

1. Általános szótárak és tulajdonnevek. A köznév (nomen appellativum) és a tulajdonnév (nomen proprium) közötti alapvetö különbség évezredek óta ismert. Egyszerüen fogalmazva: az első általánosít, az utóbbi egyedít. Ennek következtében szókészleti helyzetük is eltérő, és az idők folyamán lexikográfiai kezelésük is különbözővé vált. Bár nem tartozik szorosan e cikk témájához, igen röviden érinteni kell a magyar szótártörténet kezdeteit.

A magyar nyelv és főleg a magyar szótörténet szempontjából jelentős szójegyzékek, nomenklatúrák és szótárak (pl. Schlägli szójegyzék; Pesti Gábor: Nomenclatura sex linguarum; Gyöngyösi szótártöredék; Murmellius: Lexicon; stb.) mindkét szótípust tartalmazzák, mondhatni természetes módon. A középkor müveltségét meghatározó latin nyelv szavainak elsajátítását szolgálták ezek a müvek is, illetve a latin szavak tükrözték a szükebb és tágabb világ valóságelemeit is. Ezek közé nemcsak köznevek, hanem tulajdonnevek is tartoztak. A kezdetben csak latin nyelvü szójegyzékek idővel kiegészültek más nyelvek szavaival is, megteremtve ezáltal a későbbi két- vagy többnyelvű szótárak alapjait. A szójegyzékekben található tulajdonnevek közül föleg a helynevek voltak fontosak, hiszen egy-egy ország vagy város megnevezése a latinban és az egyes nemzeti nyelvekben lényegesen eltérő lehetett, ami az adott földrajzi objektum azonosítását is megnehezítette vagy akár lehetetlenné is tette. A gyakorlati célú lexikográfiai müvek - egyszerüen szólva a mai értelemben vett két- vagy többnyelvủ szótárak - Murmelliustól kezdve (1533) Szenci Molnár Alberten (1604) és Pápai Páriz Ferencen át (1708) a mai napig tartalmaznak személy- és helyneveket magyar és megfelelö idegen nyelvi formában.

Minden írott (illetve a 19. század végétől kezdve rögzített hangzó) nyelvi megnyilvánulás az idő múlásával a nyelvek történeti vizsgálatának anyagaként használható. Ilyen nyelvi anyagnak tekinthetők az egyes múltbeli korszakokban vagy napjainkban készült, az adott társadalmi, gazdasági és müveltségi ismereteket lexikálisan tükröző két- és többnyelvü, az értelmezö, a táj- és különféle szakszótárak, melyek - amint arra fentebb utaltam - akár tulajdonneveket is tartalmazhatnak. Az ilyen jellegü szótárak akár csak érintőleges vizsgálata kívül esik ennek a tanulmánynak a keretein (igyekezetem szerint jól megokolt kivétel az alábbi 2. pontban tárgyalt CzF.). Írásomban ugyanis csak azokkal a szótárakkal foglalkozom, amelyek a különféle primer forrásokból származó lexikális anyagukkal - beleértve az említett szótártípusokat is - nyelvi-kronológiai(-etimológiai) tekintetben a tudományos kutatás számára szekunder, ám rendkívül fontos forrásul szolgálnak. Hasonló okokból nem foglalkozom a mai magyar lexikográfia legjelentősebb munkálatával, A magyar nyelv nagyszótára (Nszt.) folyamatosan megjelenő köteteivel sem. Ez az évtizedek óta várt kézikönyv alapvetően értelmező szótár, amely azonban történeti perspektívájú abban az értelemben, hogy alak- és jelentésváltozatait az 1772-től (egyelőre) 2010-ig publikált különféle jellegü forrásokból származó idézetekkel mutatja be.

* A tanulmány az 124127-es számú NKFIH-pályázat (Új magyar etimológiai szótár. Második ütem) támogatásával készült. Köszönöm anonim lektoraim javaslatait, amelyek révén írásom tartalmasabb és értékesebb lett. 
Ezen idézetekben természetesen tulajdonnevek is szerepelnek, ám ezek nem érintik egyegy címszó jelentéseinek értelmezését, és - értelemszerüen - semmiféle közvetlen etimológiai vagy nyelvtörténeti vonatkozásuk sincs. (Az előzőekben említett szótártípusok történeti áttekintéséhez vö. FÁBIÁN ed. 2011, 2012; MURÁTH szerk. 2014.)

2. A CzuCzor-Fogarasi-féle szótár és a tulajdonnevek. Mielőtt rátérnék arra, hogy a szorosan vett történeti és etimológiai szótárak miként kezelik a tulajdonneveket, ilyen összefüggésben szólni érdemes a 19. század közepének kiemelkedő lexikográfiai alkotásáról, a CZUCZOR-FOGARASI-féle szótárról. A magyar nyelv szótára (CzF.) a Magyar Tudós Társaság (ma: MTA) 1844. december 16-ai nagygyülési határozata értelmében csupán értelmező szótárként készítendő el, de a végső változat szócikkei számos esetben tartalmaznak nyelvtörténeti és etimológiai megjegyzéseket is. Ezért néhány sorban foglalkozom azzal, hogy ezek az utalások miként jelennek meg a szótárban.

A CzF. 1. kötetének 3. lapján olvashatunk ,a szótárba tartozó egyes szókról”. Témánk szempontjából a következő szakaszt kell kiemelni: „Családok, nemzetek, országok, tartományok, városok, hegyek, vizek, helységek stb. tulajdonneveik, mivel a szófejtegetésben felvilágosítást adhatnak, szinte felveendők, mint: magyar, cseh, Örs, Sajó, Pécs stb." [kurziválások az eredetiben - G. K.]. Ennek megfelelően - csupán földrajzi helyzetükre utalva - kisebb települések nevét is megtalálhatjuk. Ilyenek például: Abácsfalva 'falu Udvarhely székben'; Abád 'falu Heves megyében'; Leányvár 'faluk Esztergom és Zemplén, puszta Tolna m.[egyében]'; stb. A nagyobb városok közül csak kettőt említek, melyeknél a szócikk bizonyos történeti és (gyakran nem helytálló) etimológiai vonatkozásokat is közöl:

Buda: (1), Magyarország iker fővárosainak egyike. [...] Nevét Kézai krónikája szerént Buda fejedelemtől, Ethele (Attila) testvérétől vette.

Debreczèn, Dẻbrẻczèn: (1), tősgyökeres magyar városaink egyik legnagyobbika, Bihar megyében. [...] Némelyek szerint a tót dobra zem (jó föld) vagy dobrá tzená (jó vásár) szókból származott volna.

Csupán megemlítem, hogy természetesen megtaláljuk a szótárban a Bakony-t, a $B a$ laton-t, a Duná-t és más földrajzi objektumok nevét is.

A személynevek közül is lássunk néhányat:

András: Közvetlenül Andreas-ból vétetett, mely hellen elemzés szerint jelent férfiast, erőst. Máskép: Andorás, Andris, Andor, Endre, kicsinezve: Andriska, Andorka; elötéttel Bandri, Bandi.

Álmos: 1) Alunni kivánó, aki alhatnék. [...] 2) Sok alvást szerető, gyakran aluvó, illetőleg tunya. [...] 3) Álmok fejtegetésével foglalkodó. [...] 4) Mint fó és személynév Ügek fiának és Árpád vezér apjának neve, melyet a névtelen jegyző főképen az álom szóból elemez, minthogy, úgy mond, születése anyjának álmában jósoltatott meg. Bíborban született Koszta leirása szerént: Salmutzes. [...] Régi oklevélben (1270-ből) előfordúl Álmod (Olmud) is mint személynév. Álmosnak neveztetett Kálmán király testvére is.

Ilona: (hellén eredetü, am. világító, fényes, $\varepsilon \lambda \varepsilon v \eta$ am. fáklya vagy $\varepsilon \lambda \eta$

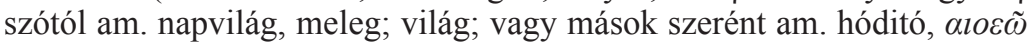


igétől); női kn. tt. Ilonát. Helena. [...] Kicsinyezve: Ilonka, Ilu, Iluska, Ilka, Ikó, Ila, Pila.

Veronika: (1) női keresztnév, a görög phereniké szótól, mely am. győzelemhozó, győzelmes.

Amint a fentiekből kiviláglik, a CzF. szerkesztői a népneveket is a tulajdonnevek közé sorolták, és számos ilyen szó hosszabb-rövidebb szócikkekben meg is található a szótárban.

3. A tulajdonnevek a történeti lexikográfiában. A továbbiakban a ténylegesen nyelvtörténeti és etimológiai szótárakat tekintem át a tulajdonnevek kezelése szempontjából. A 3.1. részben a nyelvtörténeti, a 3.2. részben a (történeti és) etimológiai kézikönyvekről írok. (Ezen szótártípusok általános jellemzéséhez vö. KISS 1994.)

\subsection{Nyelvtörténeti szótárak}

3.1.1. A magyar történeti lexikográfia kezdetei a 19. század közepéig nyúlnak vissza. JERNEY JÁNOS történész a korabeli kutatásokat hátráltató helyzetként értékelte, hogy nem állt rendelkezésükre olyan gyüjtemény, amely a különféle oklevelekben és krónikákban található magyar szavakat tartalmazná. Ezt a hiányosságot megszüntetni akarván adta közre a Magyar nyelvkincsek Árpádék korszakából címü, két füzetből álló művét. Az Előszóban a következőket írja: „E’ hézagot kívántam betölteni, midőn az árpádiak korszakát a' XIV-dik század első évéig fölkarolva, a' hely-, határ-, vidék-, hegy-, völgy-, erdö-, folyó-, család-, személy-, hivatal-, eszköz- 's egyébb ide vonatkozó, bármirészben magyar szóértelmet tartalmazó neveket és szólásformákat összegyüjtvén, szótáralakban körülbelöl mintegy ötezer vezérszóval ellátva közrebocsátom” (JERNEY 1854: V). A felsorolásból látható, hogy a feldolgozott szóanyag lexikális jellege eléggé vegyes.

Találunk benne közszavakat, sőt ezeknek különféle jelezett vagy ragozott alakjait is:

Adjon: Oggun 1 Hb.cs [cs = cselekvő ige] (mond: agygyon).

Áldomás: Aldamas, Aldumás Bknj [Béla király névtelen jegyzője] 16, 22 „Et in eodem loco (Tarczal hegyen) more paganismo, occisso equo pinguissimo, magnum aldamas fecerunt”. „Et more paganismo fecerunt aldumás” pogány szertartásu áldozat, mely lakomából állott főleg.

Párkány: Parcan 1295 „Ad erteriorem munitionem castr (Gimus), quae vulgariter Parcan dicitur" vár külső része, Nitrában.

Teremté: Terumteve $1 \mathrm{Hb}$ (m: terüntevé [Sic! - G. K.]) cs.

A szótári anyag túlnyomó része tulajdonneveket tartalmaz, amelyek között természetesen igen sok olyat találunk, amely valamilyen közszóból keletkezett. A személynevekre vonatkozóan a következőket írja JERNEY: „Szótárunkban nem kevés oly anyagra találand a' figyelmes olvasó, melyből az ős magyar nép szokása, gondolkozása és életmóda tanulságos vonásokban tünik föl. Ime sajátságos férfi nevek például, Alacsony, Bekegő, Bikacső, Bors, Büszke, Csekelő, Haragos, Irgalom, Irigy, Jólegény, Kemény, Kenő, Kevély, Keverék, Lipe, Lusta, Lökő, Maradék, Medve, Nőetlen, Ortó, Öklelő, Rigó, Serkentő, Szegény, Szomorka, Tagadó, Tekerő, Titok, Vendég, Vénlegény, Villám, Zúzó, a’ nőnevek közt továbbá: Ajándok, Banya, Csókadó, Drága, Gyönyörü, Játék, Jobbcsecsü, Kecs, 
Kúpcsecs, Liliom, Szép, Szerelmes, Szerető, Tükör, Utáló, Viola 'stb. sokkal jellemzőbbek, semhogy a' népéletre belülök eredményeket nem vonhatnánk" (JERNEY 1854: IX) - ehhez különösebb hozzáfüznivalónk nincs.

A személynevekhez kapcsolódóan, de már a helynevekre utalva írja a szerző a következőket: „Nem levén czélom magyar Onomasticon írása [...], azon személyneveket, melyek kéttelenül görög vagy római eredetü martyrologiai nevekböl alakulván, magyarban jelentéssel nem bírnak, minők például: Csepán, Deső, Isop, Jákó, Mikó, Pető (Stephanus, Desiderius, Josephus, Jacobus, Nicolaus, Petrus) stb végképen mellőztem; ellenben mint helynevet besorolám az ilyekből magyar ragok hozzájárultával alakultakat, minők: Jánosd, Miháld, Samud stb.” (JERNEY 1854: VIII). A helynevek között a településnevek mellett víz- és dülőneveket is szép számban találunk:

Adony: Odun 1208 szn; Odon 1262 hn; Addon 1279 hn Fejérben.

Ágas-halom: Agosholm 1229 VR 358 § hrhegy [hrhegy = határhegy] Kolosmben Erdélyben.

Árok-töve: Aruktue 1055 hr [hr = határ].

Barcs: Barch 1248, „Ad stagnum Barch,” tó Csallóközb.

Esk-üllő: Esculeu Bknj 27 ,In loco illo, qui dicitur Esculeu, fidem cum juramento firmaverunt, et a die locus ille nuncupatus est Esculeu, eo, quod ibi juraverunt" most Esküllö fu [fu = falu] Dobokában Erdélyben.

Fejér-Körös: Feyerkeres 1299 fó [fó = folyó] Békésben.

Az adatokat évszám követi, de a források megadása általában hiányzik: JERNEY ezt helytakarékossággal indokolta. Ha egy-egy adat a Halotti beszédből, Anonymustól, Kézaitól vagy a Váradi regestrumból származik, a lelőhelyre utalás nem marad el. Ilyen módon ez a szótár korlátozottan használható, de mindenképpen fontos mü a tulajdonnevek kutatását tekintve. Ezt az erényét még az sem kisebbíti, hogy eredetmagyarázat egyik szócikkben sem található.

3.1.2. 1865-ben a Magyar Tudományos Akadémia megbízta a nyelvész és történész MÁTYÁS FLÓRIÁNt egy nyelvtörténeti szótár összeállításával. Az MTA tagja össze is gyüjtötte $z s$ betüig a Magyar nyelvtörténeti szótárba szánt anyagot, ám a közzététel a borul igénél abbamaradt. Ennek oka a mü iránti érdektelenség volt, a második füzetből alig kelt el néhány tucat. A szótár címszavai elsősorban közszavak, azonban ezek szócikkeiben is találunk személy-, illetve helynévi adatokat:

Aczél: 1. Személynév. Ioannes dictus Achyl. 1340, C. D. VIII. 4. 474.; 2. Helynév. Achelkirtus possessio. 1386. C. D. VIII. 4. 268.

Agyag: ,Vadit ad quemdam [Sic! - G. K.] locum Ogyoguozuw vocatum” 1262. C. D. VII. 3. 46.

Bika: 1. férfinév. „Beko et Bika cum uxoribus filiis et filiabus.” 1198. Mon. 11. 194. 2. taurus.

Bogár: 1. személynév. „Artifices hy sunt: filius Buhte, bogar filius Boda” 1211. Mon. 8. 108. [...] 2. insectum, musca.

Ezek mellett olyan címszavak is szerepelnek, amelyek csupán tulajdonnévként adatolhatók: 
Aladár: Férfinév. Filiis Ivanca de Peeth, nec non filiis Aladarii fratris eorumdem. 1295. C. D. VII. 2. 183.

Antal: Férfi keresztneve, Antonius. „Castrenses de villa Mogorey, una cum Antalo filio Vytalus de Maach.” 1277. Mon. 9. 94.

Bora: Barbara. Ozthan Bornemizza Boranak adak az feldeth. 1554. R. M. Ny. E. III. 11.

A fenti példákból látható, hogy a szócikkek megfelelnek a filológiai elvárásoknak: az egyes adatokat évszám és forrásmegjelölés követi, így az adatokat ellenőrizni lehet. MÁTYÁS FLÓRIÁN müve is heterogén tartalmú, köz- és tulajdonneveket egyaránt közlö szótár, ami nem meglepő, hiszen az adott korban ez általános jelenség volt. (Csak az érdekesség kedvéért: a Béla névre vonatkozó adatok és különféle fejtegetések öt hasábot töltenek meg.)

3.1.3. A 19. század vége felé jelent meg SzARVAS GÁBOR és SimONYI ZSIGMOND szerkesztésében a Magyar nyelvtörténeti szótár (NySz.). Az 1. kötet ii. lapján a 3. pontban azt olvashatjuk, hogy a szótárból „ki kell rekeszteni [...] b) a tulajdonneveket, kivéve a keresztneveket, népneveket, s azokat, melyek egy-egy köznévnek magyarázatául szolgálhatnak (pl. Alsó-Ör, Felső-Ör sat.); [...]”. A xvii. lapon már az áll, hogy a szótárhoz csatolandó függelékben fognak majd állni a keresztnevek és „,népnevezetek”. Ennek ellenére a szótári szócikkek között találunk népneveket is, ám csupán néhányat, azokat is csak kiismerhetetlen szempontok szerint válogatva. Mondhatni, természetesen címszóként szerepel a magyar, és érthető a tót és a kun (az NySz.-ben kún) szerepeltetése is, bár az utóbbi népnév adatolása mindössze egy-két szólásra korlátozódik. A magyar nyelv (és nép) történetét tekintve ugyanígy várható lenne a magyar írásbeliségből jól adatolható besenyö, cseh, német, szász és egyéb népnév felvétele is, ezeket azonban hiába keressük a szótárban. - Az NySz. végül is nem tartalmazza azt a függeléket, amelyben ígérete szerint a kereszt- és népneveket sorolta volna föl (1. még az OklSz.-ról írottakat).

3.1.4. Az NySz. pótlékaként elkészített Magyar oklevélszótár (OklSz.) bevezetésében (Az anyag kiaknázásának elvei; különösen: XI-XIII) ZOLNAI GYULA hosszasan foglalkozik a tulajdonnevek kezelésének kérdésével. Mivel szótárát a régi közszók gyüjteményének tekintette (miként a szótár anyagának jelentős részét összegyüjtő SzAMOTA ISTVÁN is), a tulajdonneveket kihagyta a szótárból, de kijelenti: „A tulajdonnevek történelmi és hangtörténeti fontosságát egyetlen nyelvész sem vonta kétségbe, de helyesen jár el a nyelvtudós, ha a neveket tudatosan különválasztja a szóktól, s mikor szótárt készít, nem vegyít ebbe olyan elemeket, melyeknek tárgyalása külön neveskönyvbe (onomasticon), illetőleg a történeti hangtanba való" (OklSz. XI) (a kurziválások az eredetiben - G. K.). Álláspontjának megfelelően az OklSz.-ban csak akkor szerepelnek hely- és személynévi adatok, ha azok magyar közszókat tartalmaznak, ez utóbbiak szócikkébe sorolva öket. Az eljárás bemutatására álljanak itt néhány szócikkből megfelelő adatok:

Bérc: 1258: ad locum qui dicitur Kuzepberch; 1338: In loco Meggyesmaalberchy dicto; 1448: In ascensu cuiusdam montis wlgo Zeenheghetew Bercz vocati; stb.

Bükk: 1203/1254: In loco qui dicitur Bycfeu; 1337: A quodam loco Bykzad vocato; stb. 
Hév (hő): 1288/1326: In fluuio Heuyo constructum; 1394/1446: Iuxta quendam monticulum wlgo Hewhalom vocatum; stb.

Nyak: 1379: Tendendo per idem Berch in vno loco Babolna naka nominato.

Só: 1200 k.: Usque ad fluuium Souyou; 1411: in loco Thalaborsowa vocato; stb.

A fenti, viszonylag jól érzékelhető szerkezetü helynevekkel szemben vannak olyanok is, amelyek önálló szócikket kaptak. Ezekről ZOLNAI a következőket írja: „Beretytyó-t, Erdély-t - megvallom - elvemtöl eltéröleg vettem föl külön cikkekben, csupán azért, mert teljes bizonyossággal kimutatott alkotó elemeik (berek+jó, erdö+elv) anynyira elhomályosodtak már, hogy a szótár minden használója bizonyára mai egybeforrt alakjuk szerint s nem alapszavaiknál keresné őket, azonban az alapszóknál is megtalálja az olvasó a szükséges utalásokat” (OklSz. XII). Úgy gondolom, helyeselhető ez a szerkesztési gyakorlat.

A szótárba - általános kivételként - felvett keresztnevekkel kapcsolatban a következőket olvashatjuk: „A keresztnevek ugyanis mintegy a tulajdonnév és köznév határán állanak, természetüknél fogva minden más névnél jóval sürübben fordulnak meg ajkunkon, nyelvünk természetéhez legjobban simultak, s nagyobbára teljesen magyaros alakot öltöttek, úgyhogy tanulságos fejlődésük föltüntetését szótáram céljához sokkal közelebb állónak tarthattam" (OklSz. XII). Ezzel egyben az NySz. ígéretét is beváltotta az OklSz. Lássunk néhány példát keresztnévi szócikkekből:

András: 1225: Endre; 1242 k.: Endere; 1282 k.: Andreas; 1321/1323: Kenchesandrasfolua; 1336: Scenth-anduryas; 1602: Andor; stb.

Bálint: 1558 k.: ? Baint; 1577: Walent, Walint; 1584: Balynth; stb.

Ërzsëbet: 1244 k.: Ersebyth; 1334: Scentelsebeth; 1451: Zenthersebeth; stb.

Az Ok1Sz. a - $d$ és - $d i$ képzős származékokat (a származékságra való utalással) szintén a megfelelő alapszó szócikkében közli, mivel a szerkesztő szerint ezek a szavak „csupán hely- és személynevekül szolgáltak, melyeknek ennélfogva közszói minőségük alig lehetett” (XIII). A következő szavak illusztrálják ezt a szintén elfogadható eljárást:

Balog: 'balkezes; rosszindulatú' - 1230: Villa Bolugd; 1234: Ad caput arbustorum Bolugd.

Bárány: 1266/1297: Villa Barand; 1358: Possessionum [...] Barand.

Szamár: 1171: In uilla Zamard; 1211: ad stagnum Somardy.

Összességében elmondhatjuk, hogy az Ok1Sz. jól átgondolt elvek alapján közöl tulajdonneveket egy olyan szótárban, amely alapvetően köznevek szótörténeti adatait tárja az olvasók elé.

3.1.5. A történeti szótárak keletkezési időrendjében haladva röviden szólni kell a SZILY KÁLMÁN szerkesztette különleges müről, A magyar nyelvújítás szótáráról is. Mint közismert, a 18-19. század fordulójának legjelentősebb nyelvi és kulturális mozgalma, a nyelvújítás számos új szóval gazdagította időlegesen vagy tartósan a magyar szókészletet. 
A mű szerzője a következőket írja az előszóban: „Íme, a mit igértem, kedves olvasóim, előttetek fekszik ,a magyar nyelvújítás krónikája“, szótári alakban. Semmi egyéb, mint krónika; se nem teljes, se nem tökéletes” (NyÚSz. VI). Az egyes szócikkekből megtudhatjuk, ki, mikor és mely müvében (esetleg levelében) használta először az adott szót, illetve számos esetben azt is, hogy milyen más javaslatok születtek egy-egy fogalom, jelentés megnevezésére. A két kötetből álló, gazdag szómutatót tartalmazó szótár címszavainak túlnyomó többsége természetesen közszó, de a tulajdonneveket is érintette a nyelv iránt elkötelezettek magyarítási buzgalma, így ilyen lexikális anyag is színesíti a szótárt. Lássunk néhány példát előbb a helynevek köréből:

Budapest: Széchenyitől (1831: Világ, 331) idéz SzILY: „fővárostok nevét Budapestre kellene változtatni, melly kevés év, sőt hónap mulva olly megszokottan s könnyen hangzanék mint Bukarest" (NyÚSz. 424) - Pest, Buda és Óbuda 1873-as egyesítésekor vált ez a név az ország fővárosának hivatalos nevévé.

Tátrafüred: a németül Schmecks-nek nevezett településnek 1839-ben az ott alapított fürdőről a Nagyszalóki fürdö, 1842-ben a Tátrai-fürdő magyar nevet ajánlották. Ebböl alakult a Tátrafüred, mégpedig a következöképpen: „1846 július 31-ikén az akkor ott (Schmecksen) mulató közönség nevezte el e helyet, a regényes Balaton-Füred pendantjáúl” (NyÚSz. 584).

A német Leipzig magyarításaként keletkezett Lipcse szócikkét talán érdemes teljes terjedelmében közölni:

Lipcse: Sá nd or I s t ván 1791 (Sokféle 2:112). - A 112. lapon Liptse, holott u. o. 104. lapon meg Lájptzig és még 4: 34 is Liptsét rekeszben Lajptziggal magyarázza. Bizonyosan a régi Lipsia és a liptómegyei Lipcse csengett a fülében. Így ő Jenát Jenőnek, Bolognát Abonynak, Thebaet Tabánynak, Bern-et Berénynek akarta nevezni. Még furcsább: Dresda Darázsd, Kopenhága: Kappanhágó; Stockholm: Istókhalma; Solothurn: Szólótorony; Julius Caesar: Gyula császár; Kalendarium Julianum: Gyulai Kalendárium. (Sokféle 2: 110-115; 4: 233; 12: 220-243). Vö. Adal. 301.Dugonics (Jólánka 1:599) egész komolyan állítja, hogy Riga régente Rigó volt (NyÚSz. 210).

A személynevekkel több szócikk is foglalkozik, de a Keresztnevek címszó (NyÚSz. 172) alatt jó néhány olyat találhatunk, amelyek ebben az időszakban keletkeztek: Aranka $(\sim$ lat. Aurelia), Bódog ( lat. Felix), Frigyes ( ném. Friedrich), Gyözö ( lat. Victor $)$ stb. A szócikk végén a következőket írja SzILY: „Érdekes lenne kikutatni, hogy az újabb időkben kik nevezték magukat legelöször Álmos, Árpád, Attila, Béla, Elemér, Géza, Gyula, Jenö, Kálmán, Ödön, Szabolcs, Tihamér, Zoltánnak stb."

Ismert lehet, hogy az Etelka (NyÚSz. 83, 172) és Jolánka (NyÚSz. 492) női nevet Dugonics András alkotta, a Szilárd (NyÚSz. 308) pedig előbb köznévként gyökeresedett meg (Szemere Pál leleménye az 1816 elötti időből).

A NyÚSz. nagy érdeme, hogy a dolog természeténél fogva hiányos anyag bemutatásával lehetővé tette a nyelvújítás korának mind a köz-, mind a tulajdonnevek állományát érintő szótörténeti feltárását. 
3.1.6. A magyar történeti szótárak között kiemelkedő helyet foglal el a SzABÓ T. ATTILA által elindított Erdélyi magyar szótörténeti tár (SzT.). Ez a monumentális szótár valójában SzABÓ T. ATTILA erdélyi helynévtörténeti gyüjtésére épül, melyet az egykori kolozsvári kutató eleve egy más, nem szótári jellegü nagy munkában szándékozott közreadni.

A müfaj jellegzetességeiből fakadó módon ebben a szótárban is elökerül az a kérdés, hogy milyen szóanyag kerüljön be az egyes szócikkekbe. Az alaphelyzet itt is világos: csak közszavak alkotnak önálló szócikkeket. Tulajdonnevek azonban közvetett módon jelen vannak ebben a szótárban is. Más történeti (és etimológiai) szótárakhoz hasonlóan köznevesüléssel létrejött szavakat itt is találunk; pl.:

asztrakán: 'prémfajta' - 1807: (Vásárolt) 3 Astragánt; 1809: ásztrokányal; 1838: Asztrakán; stb.

atilla: 1851: Atilla; 1857: átilla.

fukar: 1722: fukár, fukar.

Bizonyos összetételekben és jelzős szerkezetekben álló tulajdonnevek is szerepelhetnek címszóként; pl.:

Péter-alma: 'almafajta' - 1697: Bán Ferencz hagyot két Almafát ... edgyik Péter alma, másik mosolygó.

Mátyás király barna pénze: 'bronzdénár' - 1637/1639: Matthjas kiralj barna penze njom M. 3 p. 34.

János király tallérja: 'Szapolyai János pénze' - 1584: Bakj pal ... Illie(n) ezwst marhakat Newez vala ... wgy mint Serlegeket, Mosdot, poharokot János kiralj tallért es egj eoregh maiczos parta eowet; 1611: Egj János kiralj tallér, egj mas Rendbelj talleral egiwt nio(m) p. 14 f. 2. d. 62 .

Számos olyan címszó is található az SzT.-ben, amely helynévböl jött létre - $i$ képzővel, különösen olyan nevekböl, amelyek alaki viselkedése nyelvtörténeti szempontból is érdekes; pl.:
alfalvi: 'gyergyóalfalusi' - 1610: Alfalj; 1647: Alfalvi; 1658: Alffaluj. bonchidai: 1591: Bonczidai; 1717: Bonczhidai.
borgói: 1670: Borgai; 1757: Borgoi.

A legtöbb (feltehetőleg több ezer) tulajdonnév számos közszói szócikkben az Án (= állatnév), Hn (= helynév) és Szn (= személynév) szakaszokban található, és ezzel gazdag tárházát kapjuk az értékes szótörténeti adatoknak. Lássunk néhány példát erre a megoldásra is:

borjú: Hn. 1695: az Borjú Ret; 1757: A Bornyu Mező, a holl az egész Falunak Bornyai Szoktak Nyaralni; 1765/1801: a Borjú motsár; 1768: A Bornyu kútnál; 1850 k.: Borjú gyepü.

boros: Szn. 1497: Johannem Boros de Zenthgrazia; 1569: Boros Kristóf; 1685: Boros Borka. 
csákó1: 'szétálló, felfelé görbülő' - Án. 1805: Második Pár ökör . . . a Tsáko Tsábéli, a Jámbor hojszbéli; 1807: Csákó fekete szarvú... ŭszŏ.

diós: Hn. 1526: dyoskerth vocitatus; 1672: az Dijos berekben; 1687: Az Diós Irtoványban; 1716: A Diós veremben; 1725: az diós bungordban; stb.; Szn. 1584: Diós Balinth.

macska: Hn. 1604: Az maczka vereon aloll az szekeres fejebe az keozen eghette(m) zenet; 1726: Az Matska nyuzo domb alat; 1805: A' Matska lik nevü helyben; 1811: Matska szék oldala nevü hellyben; 1864: Macska Mály.

Az SzT.-ben található (közvetett vagy közvetlen) tulajdonnév-állományt gazdagnak mondhatjuk. Ez egyrészt a feldolgozott források jellegéböl fakad, hiszen a különféle birtokösszeírások, peres eljárások jegyzőkönyvei, városi-községi tanácsi hivatalos iratok, anyakönyvek, adásvételi szerződések, misszilisek stb. ezrével tartalmaznak hely- és személyneveket egyaránt. Másrészt ez a szótár kifejezetten törekedett a címszó-gazdagításra, és ezáltal olyan címszavak is keletkeztek, amelyek a korábbi (és nagyrészt a mai) magyar lexikográfiában nem állnak ilyen helyzetben. Ilyenek általában a jelzős szerkezetek, az - $i$ képzős alakok (hacsak nincs jelentésbeli többletük) stb. Ám SzABÓ T. ATTILA ezzel az eljárással (és egyéb szerkesztési megoldásokkal) arra törekedett, hogy minél több olyan nyelvi anyagot mentsen meg és tegyen közzé, amely más formában hozzáférhetetlen lenne a szakemberek vagy az érdeklődő laikus olvasók számára.

3.1.7. A magyar történeti szótárak sorában fontos helyet foglal el egy, a maga nemében egyedülálló szótár. Ez a BERRÁR JOLÁN és KÁROLY SÁNDOR szerkesztette Régi magyar glosszárium (Gl.), mely az alcíme szerint Szótárak, szójegyzékek és glosszák egyesített szótára. Lexikográfiai és nyelvtörténeti jelentőségét nem lehet eléggé hangsúlyozni, hiszen nélküle igen nehézkes lenne a sokféle helyen örzött, nem is mindig megfelelö formában publikált lexikális anyag felhasználása. Az 1290 körül keletkezett Vatikáni glosszákkal és az 1610 körüli időből származó Herbolarium Vincentiae-vel jelölhető időhatárok közötti ötvenhét forrás is tartalmaz természetesen tulajdonneveket, és ezeket a Gl. is közli: elkülönítve a közszavaktól, a szótár végén, mintegy függelékként. (A szótár közszói részében bizonyos szintagmák tagjaként is előfordulnak tulajdonnevek, amelyekre az adott tulajdonnév szócikkében mindig utalás történik.) Ha egy-egy tulajdonnév - $i$ vagy -beli képzővel is előfordul, ez az alak a közszavak között szerepel címszóként, természetesen utalással a megfelelő névre, illetve a névnél utalást találunk a közszói címszóra.

Sajátosnak tünik a szerkesztőknek az az eljárása, hogy a tulajdonneveket nem a ma megszokott köznyelvi alakjukban teszik meg címszónak, hanem a forrásokból adatolható korabeli, sokszor latinos formában. Ez a megoldás az egyénneveknél kevésbé okoz gondot az azonosíthatóság tekintetében, hiszen az Asveros, illetve a Jovis viszonylag könnyen „transzformálható” a ma használt Ahasvérus, illetve Jupiter formára. Viszont az Udalrikus vagy a Korlát esetében már gondban lehetnénk, ha a címszóként álló nevek után nem állna ott németül a ,jelentésük”, vagyis a mai magyar névformával azonosítható német megfelelö. Ilyen módon az első esetben az Ulrich, a második esetben a Konrad névnek a korabeli (meglehet, hibásan lejegyzett, esetleg népetimológiás) alakjával van dolgunk. A személynevek között (érthető módon) viszonylag számos adata van a János és a Mária keresztnévnek. 
A helynevek közt természetesen sok olyat találhatunk, amelynek korabeli és mai névformája (ejtésformája) azonos: Ázsia, Balaton, Garam, Hollandia, Székesfehérvár stb. Több olyan helynév is van, amelyet ma már nem használunk, de történelmi ismereteink segítségével lokalizálni tudjuk őket: Antverpia, Athénás, Florencia, Helvécia, Slézia stb., de a német megfelelök itt is segítségünkre vannak.

A helynevek közül a német értelmezések nélkül viszont számosat aligha tudnánk mai megfelelöikkel azonosítani. Lássunk ezekre is néhány példát: Aretopolis 'Bern', Argentína 'Straßburg' [!], Briganton 'Bregenz', Gedanon 'Gdańsk', Leopolia 'Lemberg' stb.

A Gl. köznévi része mellett a tulajdonneveket bemutató szócikkek is jól használható adalékokat tartalmaznak a magyar történeti onomasztikai kutatások számára.

3.2. Etimológiai szótárak. A tisztán történeti szótárak után áttérünk az etimológiai szótárakra. Ezek közül a hangsúlyosan tudományos igények kielégítésére törekvő szótárak a szóeredeztetés mellett szótörténeti adatokat is közölnek, hiszen megalapozott etimológiát általában nem lehet szótörténet nélkül felállítani.

3.2.1. Időrendben haladva a GOMBOCZ-MELICH-féle Magyar etymologiai szótárral (EtSz.) kell kezdenünk. Ennek a kézikönyvnek sajátos módon nincs bevezetője, melyből a különféle szerkesztési elvekre, megoldásokra vonatkozó információkat szerezhetnénk. A füzetekben megjelenő szótár hátsó borítójának külső oldalán azt olvashatjuk, hogy a köznyelv szavain kívül felveszik a tájszavakat, „valamint a tulajdonnevek közül is azokat, amelyeknek világos az eredetük s amelyeknek nyelvészeti vagy történeti fontosságuk van". Ezzel követik azt a lexikográfiai gyakorlatot, amelyet már a CzF.-ben, majd (kicsit szükebb körre kiterjedően) az OklSz.-ban is tapasztalhattunk. Az EtSz. A, Á kezdetü részében a következő hely- és személyneveket találjuk: $A b a$ szn., Ábel, Ábrahám, Abrud hn., Acintus szn., Acsa hn., Ádám, Adolf, Adorján, Aglënt szn., Ágnës, Ágosta hn. (Augsburg), Ágoston, Ágota, Ajton, Akastyán-hegy, Ákos, Aladár, Alajos, Alap szn., Albërt, Álmos, Alpár szn., Amadé, Amália, Ambrus, Ancilla szn., Anda szn., András, Angyalos szn., Anianus, Anna, Antal, Apaj szn., Apalin szn., Apostol hn., Apsa szn., Arad, Árbusz szn., Ardán Ardány hn., Ardó hn., Arnold, Áron, Árpád, Árva hn., Ata szn., Aténás, Athlamos szn., Atilla, Atlanti(-tenger), Auguszt szn., Ausztria, Azariás szn. Ezeknek vagy sosem volt magyar köznévi alapjuk, vagy pedig elhomályosult morfémaszerkezetekké váltak (Ardó, Arpád), és így lehettek tulajdonnévvé. A 102 lapon 53 tulajdonnév áll címszóként; ez mindenképpen nagy számnak mondható egy alapvetően köznévi etimológiai szótárnak szánt müben. Más kezdőbetűket tekintve nyilván más (jobbára alacsonyabb) számokat kapunk, de több más tényező mellett feltehetőleg a tulajdonnevek túlzott felvétele is oka lehetett annak, hogy az EtSz. torzóban maradt.

Tulajdonneveket, föleg helyneveket a szótár köznévi szócikkeiben, a szótörténeti adatoló részben is találunk, gyakran csupán az illető adat forrására utalva, a konkrét adat közlése nélkül; pl.:

apa: 1141-61 Apa szn.

apró: 1145/1443: aprokwrthwel hn.

berek: 1138 berekzeg hn.

bika: 1193 biquacut hn.

bodnár: 1388 Bodnar szn. 
3.2.2. Második etimológiai szótárként a BÁRCZI GÉZA szerkesztette Magyar szófejtő (SzófSz.) szótárt kellene megvizsgálni. Erről a megjelenése idején hiánypótló müről szerkesztője a következőket írja: „Ez a szófejtő szótár nem a szakembereknek, hanem elsősorban a müvelt magyar közönségnek szól” (SzófSz. V). Ennek következtében a szócikkek alapvetően a legfontosabb etimológiai információk közlésére szorítkoznak. A szótörténet pusztán annyiból áll, hogy közli az első adat keletkezési idejét és forrását. Ha egy-egy szó első adata személy- vagy helynévből származik, erre a hn. (= helynév), illetve szn. (= személynév) rövidítés utal, majd következik az első köznévi adat évszáma, lelőhelye, pl.:

alma: [hn. összet. 1236/1239. OklSz., kn. 1225. OklSz.]

bíz: [szn. szárm. 1211. MNy. 31: 159, kn. XIV. sz. v. BesztSzj.]

hős: [szn. 1206. NySz., kn. XIV. sz. v. BesztSzj.]

mocsár: [hn. v. kn. 1231/1397. OklSz. kn. 1342. Nyr. 42: 364$]$

ösvény: [hn. 1222. Ok1Sz., kn. XV. sz. e. f. JókK. NySz.]

A SzófSz. - mint láthatjuk - magától értetődő módon elismeri a tulajdonnevek fontosságát a szótörténetben, de céljainak megfelelően a mintegy 350 lapos szótár csupán utal ezekre a megfelelö szócikkekben.

3.2.3. A magyar történeti lexikográfia eddigi legnagyobb alkotása a BENKŐ LORÁND föszerkesztésében megjelent A magyar nyelv történeti-etimológiai szótára (TESz.). A mintegy háromezer lapon található, a 130 000-et meghaladó lexikális adat (szóalakok és jelentések), valamint a szócikkekben található idegen nyelvi adatok óriási száma, az etimológiai kifejtések megalapozottsága nemzetközi tekintetben is a müfaj legjobbjai közé emelték ezt a szótárt. Ez a kézikönyv már a címében is hangsúlyozza a szótörténet és az etimológia egységét, és ezt a szócikkek felépítésében is jól láthatjuk. Az egyik előzménytől, az EtSz.-től eltérően azonban semmilyen tulajdonnév nem áll címszóként: „Szótárunkban a magyar szókészletnek csak a köznévi elemeit dolgoztuk föl. A magyar tulajdonneveket (hely- és személyneveket) - mind elvi, mind gyakorlati meggondolások alapján - kirekesztettük; ezeknek történeti-etimológiai feldolgozása egy vagy több külön névtár feladata. A tulajdonnevek kirekesztése természetesen csak a címszóanyagra vonatkozik; az egyes szavak történeti dokumentációjában ezek magától értetődően nagy számban szerepelnek, hiszen a régi magyar köznevek jelentős része korai nyelvemlékeinkben hely- és személynévként fordul elö" (TESz. 1: 8). Ám a tulajdonnevek sokkal következetesebben szerepelnek a szótörténeti adatoló szakaszban, mint az EtSz.-ben. Erről a következőket olvashatjuk: „Az alakváltozatok dokumentálására a címszó származékait [...] és tulajdonnévként előforduló adatait is felhasználjuk. A származékok sz. (= származék) jelzést kapnak, a tulajdonnévi adatokat pedig szn. (= személynév), illetőleg hn. (= helynév = földrajzi név) jelzéssel látjuk el" (TESz. 1: 19). A szóalakokat többé-kevésbé jól meg lehet állapítani a tulajdonnevek esetében is, de az alakokhoz kapcsolódó jelentések elvonása ezekből már sok esetben nehézségekbe ütközik. Erre vonatkozólag a következő tájékoztatást kapjuk: „Ha a forrás nem teszi lehetővé a jelentés teljesen egyértelmű meghatározását, vagy pedig tulajdonnév alapján tüntetjük fel valamelyik jelentés első felbukkanását, akkor erre a bizonytalanságra az értelmezés szövege elé tett kérdőjellel hívjuk fel a figyelmet" (TESz. 1: 19). (Természetesen mindig szerepel az illető jelentés első biztos 
adata is.) A tulajdonnevek nemcsak a címszavak alakváltozatai között szerepelnek, hanem az Sz: rövidítéssel bevezetett, a kiemelt származékokat közlö szakaszban is; pl.:

acél: 1135 k.: ? „Tornatores: . . Acil” szn. (PRT. 8: 270); 1229/1550: ? Acél szn. (VárReg. 360.) - J: 1135 k.: ? 'edzhető vasféleség, vasötvözet; Stahl' \# (1. fent), 1395 k.: 'ua.' (1. fent) - Sz: os 1335: Acilus hn. (OklSz.).

ág: 1158/1323/1403: ? „que terminatur ... ab oriente . . . Voduez, et Agifei” hn. (Karácsonyi: Szt. István 81); 1193: egerag hn. (ÓMOlv. 55) J: 1158/1323/1403: ? 'folyó ága; Flußarm' \# (1. fent), 1193: 'ua.'(1. fent) Sz: as 1141-61: ? Agus szn. (Ok1Sz.); 1229/1550: Agosholm hn. mn. (VárReg. 358.)| azat 1510: Kewzepagazath hn. (Ok1Sz.).

bátor': 1138/1329: „Hec sunt nomina seruorum Bahatur ...” szn. (MNy. 32: 132); [1177]/1202-3/15. sz.: Batur hn. (Györffy 1: 598); 1180 k./1213. sz.: ? Buatir szn. (PRT. 8: 270); 1230: Baatur hn. (Györffy 1: 848); 1323: Bathorighaz hn. (Györffy 1: 710) - J: 1138/1329: ? 'merész, hős; mutig' \# (1. fent), 1372 u./1448 k.: 'ua.' (1. fent).

A példák számát bőven szaporíthatnánk, de az itt megadottakból is világosan látszik, hogy a tulajdonnevek a szavak adatolásának kronológiájában tapasztalható fontosságuk miatt kellő súllyal szerepelnek a szótörténeti adatok között.

3.2.4. A tudományos igényű magyar etimológiai szótárak sorában (egyelőre) utolsó a német metanyelvü Etymologisches Wörterbuch des Ungarischen (EWUng.), melynek föszerkesztője szintén BENKÖ LORÁND volt. Gyakran - és tévesen - a TESz. német fordításaként emlegetik ezt a kézikönyvet, jóllehet attól több lényeges tekintetben is eltér; ennek taglalása nem feladata ennek a cikknek. Az természetesen igaz, hogy a TESz.-ben felhalmozott szótörténeti adatok közül igen sok megtalálható az EWUng.ban is, ami nyilvánvalóan teljesen érthető dolog. Ám semmi esetre sincs szó az adatok mérlegelés nélküli ,átlapátolásáról”: a szerkesztés során alapos rostálás történt, illetve új adatok is beépültek az új szótárba. Amiben szintén hasonlóság van a TESz. és az EWUng. között, az a tulajdonnévi adatok azonos módon való kezelése. Lássuk ehhez a TESz.-ből idézett példák EWUng.-beli megfelelöit (A = származék; ON = helynév; $\mathrm{PN}=$ személynév; $\mathrm{B}=$ jelentés). (Ha az adat után nem áll forrásjelölés, az azt jelenti, hogy az adat a TESz.-ből származik.)

acél: 1086 ? Acil PN (DHA 240); 1229/ Acel PN; 1335 Acilus A, ON A: os 1335 ON.

ág: [1131-41]/ ? Agus PN; 1193 egerag ON; - A: as [1131-41] PN (?), $1229 / \mathrm{ON} \mid \sim$ azat $1510 \mathrm{ON}$.

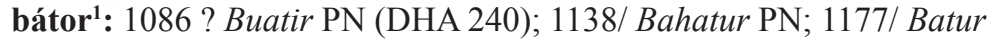
ON; 1230 Baatur ON; - B: 1086 ? 'mutig' \# (t), 1138/ 'ds'.

Elmondhatjuk tehát, hogy a tulajdonnevek szótörténeti felhasználását tekintve az EWUng. is eleget tesz azoknak a magas elvárásoknak, amelyeket a TESz. óta támasztanak a szakemberek egy jó történeti és etimológiai szótárral szemben. És csupán megemlítve: ugyanez érvényes az MTA Nyelvtudományi Intézetében készülő Új magyar etimológiai szótárra is, hiszen a tulajdonnevek kezelését tekintve nem tér el az említett két szótártól. 
3.2.5. A tényszerüség kedvéért meg kell említeni a ZAICZ GÁBOR föszerkesztésében készült Etimológiai szótárt (ESz.) is. A SzófSz.-hoz hasonlóan ez is a müvelt nagyközönség igényeit szándékozik kielégíteni. A szótörténet ebben is rendkívül szikár: lényegében az első adat évszámára szorítkozik, és csupán akkor jelöli egy-egy adat tulajdonnévi jellegét, ha az kronológiailag elsőként adatolható. Ebben a szótárban nem találunk különbséget a személynévi és helynévi adat között, egységesen a tn. (= tulajdonnév) rövidítést alkalmazzák a szerkesztők, és a tulajdonnévi adat esetleges származék volta is jelöletlen marad; pl.:

farag: [1357 tn., 1416 u.]; vö. TESz.: helynévi származék.

féreg: [1152 tn., 1372 u.]; vö. TESz.: személynévi származék.

kard: [1319 tn., 1405 k.]; vö. TESz.: személynévi származék.

4. Összegzés. Összefoglalva a fentieket elmondhatjuk, hogy a magyar szókészlet eredetével foglalkozó szótárak között (beleértve a CzF.-et is) világos különbséget tapasztalhatunk. A 19. századi ihletésü kézikönyvek (CzF., EtSz.) - bár deklaráltan közneveket dolgoznak fel - különféle indokokkal tulajdonneveket is felvesznek címszavaik sorába, és igyekeznek megfelelő etimológiát adni hozzájuk. Velük szemben a modern(ebb) szótárak a tulajdonnevek fontosságát meg nem tagadva csupán a köznévi címszók adatolásában használják ezeket, a tulajdonnévi jellegből fakadó bizonytalanságokat kellő óvatossággal kezelve. Ám ilyen módon is (különösen a TESz., de jelentős mértékben az EWUng. is) gazdag tárházát jelentik annak a müvelődéstörténeti szempontból is színes és fontos lexikális anyagnak, amelyet tulajdonneveknek nevezünk.

\section{Felhasznált források}

CzF. = CzUCzor Gergely - Fogarasi JÁnos, A magyar nyelv szótára 1-6. Emich Gusztáv / Athenaeum, Pest/Budapest, 1862-1874.

ESz. = Etimológiai szótár. Magyar szavak és toldalékok eredete. Főszerk. ZAICZ GÁBOR. A magyar nyelv kézikönyvei 12. Tinta Könyvkiadó, Budapest, 2006.

EtSz. = GOMBOCZ ZOLTÁN - MELICH JÁNOS, Magyar etymologiai szótár 1-17. füzet. MTA, Budapest, 1914-1944.

EWUng. = Etymologisches Wörterbuch des Ungarischen 1-2. Hrsg. LORÁND BENKÖ. Akadémiai Kiadó, Budapest, 1993-1995.

Gl. = Régi magyar glosszárium. Szótárak, szójegyzékek és glosszák egyesitett szótára. Szerk. BERRÁr JolÁn - KÁroly SÁNDOR. Akadémiai Kiadó, Budapest, 1984.

JERNEY JÁNOS 1854. Magyar nyelvkincsek Árpádék korszakából 1-2. K. n., Pest.

MÁTYÁs FLóRIÁN 1868-1871. Magyar nyelvtörténeti szótár[-kisérlet] 1-3. K. n., Pest/Pécs.

NySz. = Magyar nyelvtörténeti szótár a legrégibb nyelvemlékektöl a nyelvújításig 1-3. Szerk.

SZARVAS GÁBOR - SiMONYI ZSIGMOND. Hornyánszky, Budapest, 1890-1893.

NyÚSz. = SZILY KÁLMÁN, A magyar nyelvújitás szótára a kedveltebb képzők és képzésmódok jegyzékével 1-2. Hornyánszky, Budapest, 1902-1908.

OklSz. = Magyar oklevél-szótár. Régi oklevelekben és egyéb iratokban elöforduló magyar szók gyüjteménye. Gyüjt. Szamota István. Szerk. Zolnai GyUla. Hornyánszky, Budapest, 1902-1906. 
SzófSz. = BÁRCZI GÉZA, Magyar szófejtő szótár. Királyi Magyar Egyetemi Nyomda, Budapest, 1941.

SzT. = Erdélyi magyar szótörténeti tár 1-14. Föszerk. SzABÓ T. ATTILA etc. Kriterion Könyvkiadó etc., Bukarest etc., 1975-2014.

TESz. = A magyar nyelv történeti-etimológiai szótára 1-3. Főszerk. BENKÖ LORÁND. Akadémiai Kiadó, Budapest, 1967-1976.

\section{Hivatkozott irodalom}

FÁBIÁN, ZSUZSANNA ed. 2011. Hungarian lexicography I. Bilingual dictionaries. Lexikográfiai Füzetek 5. Akadémiai Kiadó, Budapest.

FÁBIÁn, ZsUZSANNA ed. 2012. Hungarian Lexicography II. Monolingual and Special Dictionaries. Lexikográfiai Füzetek 6. Akadémiai Kiadó, Budapest.

KisS LAJOS 1994. Nyelvtörténeti szótáraink típusai. Magyar Nyelv 90: 392-412.

MURÁTH JUDIT szerk. 2014. Hungarian lexicography III. LSP Lexicography. Lexikográfiai Füzetek 7. Akadémiai Kiadó, Budapest.

GERSTNER KÁROLY

ORCID: https://orcid.org/0000-0003-1945-2667

Nyelvtudományi Intézet

Pázmány Péter Katolikus Egyetem

Bölcsészet- és Társadalomtudományi Kar

\section{Károly Gerstner, Proper names in historical and etymological dictionaries}

The fundamental difference between common nouns (nomen appellativum) and proper names (nomen proprium) has been known for thousands of years. Put simply, the former generalizes, the latter individualizes. As a result, their place in the lexicon is different, and their lexicological consideration has also parted ways. The study touches on how the outstanding lexicographic work of the $19^{\text {th }}$ century, the Czuczor-Fogarasi dictionary, references proper names. While the dictionary is fundamentally an explanatory dictionary, its entries often contain historical or etymological information. Beyond reference books that do not deal directly with proper names, dictionaries focusing on the history of other parts of speech also list several proper names, as the importance of these in the history of both society and language is evident to researchers. Based on the above, the study first provides an overview of the methods applied in historical dictionaries (e.g., Magyar oklevélszótár [Dictionary of Hungarian deeds], Erdélyi magyar szótörténeti tár [Historical dictionary of Transylvanian Hungarian]) and etymological dictionaries (e.g., Magyar etymológiai szótár [Etymological dictionary of Hungarian], A magyar nyelv történeti-etimológiai szótára [Historical and etymological dictionary of Hungarian]). Both dictionary types are rich repositories of data for the lexical material known as proper names. 